\title{
Government Policy on Child Crime through the Concept of Diversion as a Solution amid the Spread of Covid-19
}

\author{
Karsudin \\ Faculty of Law, Universitas Diponegoro, Semarang, Central Java Indonesia \\ Email: karsudin_undip@yahoo.com \\ ORCID Link: https://orcid.org/0000-0001-7575-0840 \\ Irma Cahyaningtyas \\ Faculty of Law, Universitas Diponegoro, Semarang, Central Java Indonesia
}

\section{Citation:}

Karsudin, K., \& Cahyaningtyas, I. (2021). Government Policy on Child Crime through the Concept of Diversion as a Solution amid the Spread of Covid-19. Lex Scientia Law Review, 5(2), 1-18, doi: https://doi.org/

10.15294/lesrev.v5i1.49914

\section{History of Article}

Received: September 14, 2021

Revised: November 11, 2021

Accepted: 19 November, 2021

(C) The Author(s)

\section{cc) (†)}

BY Ne SA

This work is licensed under a Creative Commons Attribution-NonCommercialShareAlike 4.0 International License.

All writings published in this journal are personal views of the authors and do not represent the views of this journal and the author's affiliated institutions.

Lex Scientia Law Review published by Faculty of Law, Universitas Negeri Semarang, Indonesia in collaboration of UKM Lex Scientia. Published biannually every May and November.

\begin{abstract}
This study aims to analyze the concept of diversion as an instrument to realize restorative justice, applied in the Decree of the Minister of Law and Human Rights of the Republic of Indonesia Number M. HH-19. PK.01.04.04 of 2020 Regarding Release and Acquittal of Prisoners and Children Through Assimilation and Integration to Prevent and Control the Spread of Covid-19. The research method used in this research is normative juridical using secondary legal data. Based on the results of the research, it is known that the handling of juvenile criminal cases through the concept of diversion based on restorative justice is carried out to guarantee and respect the dignity of the child, carried out in the best interests of the child and by considering justice for the victim. The government, which is represented by The Minister of Law and Human Rights, has made a very responsive policy through the Decree of the Minister of Law and Human Rights of the Republic of Indonesia Number M. HH-19. PK.01.04.04 of 2020 Regarding Release and Acquittal of Prisoners and Children Through Assimilation and Integration to Prevent and Control the Spread of Covid-19.
\end{abstract}

\section{KEYWORDS}

Diversion, Restorative Justice, Child Crime, Covid-19 


\section{INTRODUCTION}

Law in Indonesia has recognized that every legal subject has the same legal rights and obligations before the law. Even at a more abstract level, a legal adage states that "equality before the law" means that everyone has the same position before the law. This adage is a universal concept and aims to fight discrimination in law enforcement in Indonesia. ${ }^{1}$ Children in law are recognized as legal subjects but have not become legal subjects in full. There are certain specialties and exceptions specified in the law that distinguish between adults and children. Children cannot be fully charged with legal responsibility.

For example, in civil law as one of the legal requirements of Article 1320 of the Civil Code is "legally competent", which means that the condition for the validity of an agreement is carried out by a legal subject who is legally capable. One of the measures to determine that a legal subject has legal competence is the age of an already mature person. As the legal consequence of not fulfilling the conditions for the agreement's validity, the agreement can be canceled. ${ }^{2}$ Another example is that criminal law has distinguished the criminal liability of children in conflict with the law and the criminal liability of adults with the law. This is in line with the principle of criminal law "Lex Specialist Derogate Legi Generalis", which means that special laws override general law, which in the context of this study, rules regarding child crimes overrides other general rules relating to crime and the rules in the second book of the Criminal Code (KUHP) which regulates crime. ${ }^{3}$

Children are the mandate from the One Almighty God who has an inherent dignity as a whole human being. Every child has value and dignity that should be upheld, and every child born must get their rights without the child asking. This is in accordance with the provisions of the Convention on the Rights of the Child, which the government of Indonesia ratified through Presidential Decree Number 36 of 1990 and also stated in Act Number 4 of 1979 Regarding Child Welfare and Act Number 23 of 2002 Regarding Child Protection, all of which state the general principles of child protection, such as non-discrimination, the best interests of children, survival and growth and development, and respect for children's participation.

\footnotetext{
${ }^{1}$ Haris Azhar, 'Equality before the Law Dalam Sistem Peradilan Di Indonesia', Lokataru Foundation, September 6, 2018, accessed from https://lokataru.id/equality-before-the-law-dalam-sistemperadilan-di-indonesia/.

2 Agung Sujatmiko, 'Perjanjian Lisensi Merek Terkenal', Mimbar Hukum, Volume 22 Number 2, 2010, p. 259.

${ }^{3}$ Shinta Agustina, 'Implementasi Asas Lex Specialis Derogat Legi Generali Dalam Sistem Peradilan Pidana', Masalah-Masalah Hukum, Volume 44 Number 4, 2015, p. 504.
} 
According to Article 13 section (3) of Act Number 23 of 2002 Regarding Children Protection, as long as a child is in the care of parents, trustees, or any other parties, they are responsible for the protection of children from discrimination, exploitation, neglect, cruelty, violence, abuse, injustice, and other mistreatments. If section (1) is neglected, the caregiver can be punished (section (2)).

Concerning the principle of child protection, especially the principle of non-discrimination, which prioritizes the child's best interests and the right to life, survival, and child development, it is necessary to respect children, including children who commit criminal acts. Therefore, it is necessary to have a juvenile criminal justice system where there is a process for resolving child cases outside of conventional criminal mechanisms. A thought or idea arises for this way of diversion, commonly called the idea of diversion, because correctional institutions are not the way to solve children's problems, and in fact, correctional institutions are prone to violations of children's rights. This is what drives the idea of diversion, especially through the concept of Restorative Justice, to become a crucial consideration in resolving criminal cases committed by children. ${ }^{4}$

Along with justice and satisfaction of the people, the criminal law in Indonesia, especially the Criminal Code, should adapt to the times and society and the conditions in Indonesia. The philosophy of justice that wants to be upheld in dispute resolution among the community is communal justice. Communal justice is justice where no one feels aggrieved by the decisions taken by the traditional leaders in resolving disputes. This justice is fundamental to be enforced as the joint of the life order of the customary law community. Deliberation and consensus are the philosophy of the Indonesian people in every decision making, including dispute resolution. ${ }^{5}$ Deliberation and consensus have been recorded in the philosophy of the Republic of Indonesia in 4th precept of the 1945 Constitution, other laws, and regulations. Mediation with the basis of deliberation towards a peace agreement gets its own arrangement in some legal products. Alternative arrangements for dispute resolution in the rule of law are fundamental because Indonesia is a state of law. The basic idea of an alternative settlement of criminal cases is related to the nature of the Ultimum Remedium. According to Van Bemmelen, criminal law is Ultimum Remedium means that it acts as the last remedy. It is

\footnotetext{
${ }^{4}$ Nur Hidayati, ‘Peradilan Pidana Anak Dengan Pendekatan Keadilan Restoratif Dan Kepentingan Terbaik Bagi Anak', Ragam, Volume 13 Number 4, 2013, p. 147.

${ }_{5}^{5}$ Dede Kania, 'Pidana Penjara Dalam Pembaharuan Hukum Pidana Indonesia', Yustisia, Volume 3 Number 1, 2014, p. 21.
} 
limited as possible, which means that if other parts of the law are not sufficient to affirm the norms recognized by law, criminal law is applied. ${ }^{6}$

Criminal sanctions must remain an Ultimum Remedium. This does not mean that the threat of punishment will be abolished, but we must always consider the advantages and disadvantages of criminal punishment and ensure that the remedy given is not worse than the disease itself. With the nature of criminal law as an Ultimum Remedium, punishment is sought as a last resort as long as other methods are used. The existence of a case settlement outside the trial will undoubtedly resolve the conflict that occurred as a result of the crime because when the perpetrator and the victim have reconciled, it will automatically relieve the guilt of the convict because the victim has forgiven the convict. A sense of peace in society can be achieved and returned to its original condition as it was before the crime occurred. ${ }^{7}$

Discerning the reality, the settlement of cases carried out by children is still the same as adults, namely through the judicial process. The result will stamp the child as a prisoner who is worried that this situation will have a negative impact that can affect the mental and soul of the child. Moreover, the purpose of punishment to humanize humans will no longer be achieved because of procedures and methods are not properly used. ${ }^{8}$ One solution is to implement diversion. Diversion is an action or treatment to divert a case from a formal process to an informal process or place the perpetrators of child crimes out of the juvenile justice system or to place a child offender out of the criminal justice system. This means that not all cases of juvenile delinquents must be resolved through formal justice and provide an alternative for settlement with a justice approach in the child's best interests and by considering justice for the victim. In the current situation, in the midst of the spread of Covid-19, the government represented by the Minister of Law and Human Rights of the Republic of Indonesia, has issued Decree Number M.HH-19.PK.01.04.04 of 2020 Regarding Release and Acquittal of Prisoners and Children Through Assimilation and Integration in Order to Prevent and Control the Spread of Covid-19. Based on the description above, this research will specifically discuss government policies in order to overcome child crimes based on the concept of Diversion as a solution amid the spread of Covid-19, in relation to government policies regarding the release of prisoners

${ }^{6}$ Lidya Suryani Widayati, 'Ultimum Remedium Dalam Bidang Lingkungan Hidup', Ius Quia Iustum Law Journal, Volume 22 Number 1, 2015, p. 13.

7 Sri Rahayu, 'Diversi Sebagai Alternatif Penyelesaian Perkara Tindak Pidana Yang Dilakukan Anak Dalam Perspektif Sistem Peradilan Pidana Anak', Jurnal Ilmu Hukum, Volume 6 Number 1, 2015, p. 131.

8 Hariman Satria, 'Restorative Justice: Paradigma Baru Peradilan Pidana', Jurnal Media Hukum, Volume 12 Number 3, 2018, p. 118. 
and children through assimilation and integration in the midst of the Covid19 pandemic.

\section{METHOD}

The research method used in writing this article is a normative juridical method, which is legal research carried out by basing its analysis on legislation ${ }^{9}$ as positive law in Indonesia, such as Law Number 23 of 2002 Regarding Child Protection, Law Number 4 of 1979 Regarding Child Welfare, Law of The Republic of Indonesia Number 11 of 2012 Regarding Juvenile Criminal Justice System, Decree of the President of the Republic of Indonesia Number 36 of 1990 Regarding Ratification of Convention On The Rights Of The Child and Decree Number M.HH-19.PK.01.04.04 of 2020 Regarding Release and Acquittal of Prisoners and Children Through Assimilation and Integration in Order to Prevent and Control the Spread of Covid-19. This research was conducted by examining secondary data obtained from literature studies. The specification in this research is descriptive-analytical research. Types and techniques of data collection in legal research obtained through literature study. The analytical method used in this research is analytical descriptive, which is a way of analysis by describing the object under study ${ }^{10}$, then drawing a conclusion based on the research problem.

\section{RESULT AND DISCUSSION}

\section{A. The Importance of Restorative Justice Approaches in the Settlement of Child Crime Cases in Indonesia}

Children as one of the human resources and are the next generation of the nation should receive special attention from the government, especially fostering children to realize substantial and quality human resources. Concerning child development, legal facilities and infrastructure are needed that anticipate all problems that arise. The facilities and infrastructure relate to the child's interests and concern deviations in attitudes and behavior that make the child forced to be brought before the court. Love is the most basic psychic need in a child's life and the life of a child rests on the conscience of the parents. ${ }^{11}$ In fact, many parents are not aware of this, which affects the

\footnotetext{
${ }^{9}$ Kornelius Benuf and Muhamad Azhar, 'Metodologi Penelitian Hukum Sebagai Instrumen Mengurai Permasalahan Hukum Kontemporer', Gema Keadilan, Volume 7 Number 1, 2020, p. 24.

10 Yulianto Achmad Mukti Fajar, Dualisme Penelitian Hukum Normatif Dan Empiris, Pustaka Pelajar, Yogyakarta, 2017, p. 54.

${ }^{11}$ Hengki Andora, 'Aktualisasi Nilai-Nilai Pancasila Dalam Pengadaan Tanah Bagi Pembangunan Untuk Kepentingan Umum', Masalah-Masalah Hukum, Volume 45 Number 2, 2016, p. 111.
} 
development and basic needs of children's lives. Children raised in an atmosphere of conflict tend to experience mental anxiety that can encourage children to take negative actions, categorized as child delinquency. Children as perpetrators of criminal acts are called delinquent children or in criminal law, it is said to be juvenile delinquency. Romli Atmasasmita argues that juvenile delinquency is any act or behavior of a child under the age of 18 and unmarried, which is a violation of applicable legal norms and can endanger the child's personal development. ${ }^{12}$

The juvenile justice system in Indonesia which has now become the basis of the spirit in the Criminal Code Bill, which among other things changes the paradigm, includes: the purpose of punishment. ${ }^{13}$ Resolving conflicts caused by criminal acts, restoring balance and bringing a sense of peace to society; a spirit of concern for victims of crime; development of an alternative to imprisonment; specifically criminal arrangements and actions for children. In addition to the Criminal Code Bill, The Juvenile Criminal Justice System has laid down efforts for diversion and restorative justice. With the nature of criminal law as an ultimum remedium, punishment is sought as a last resort as long as other methods are used. The existence of a case settlement outside the trial will undoubtedly resolve the conflict that occurred as a result of the crime because when the perpetrator and the victim have reconciled, it will automatically relieve the guilt of the convict because the victim has forgiven the convict.

A sense of peace in society can be achieved and returned to its original condition before the crime occurred. Concerning cases of criminal acts committed by children, the settlement of the case can be carried out outside the court process, which is called diversion. Diversion arrangements have been explicitly regulated in the Juvenile Criminal Justice System Law as a legal basis for the implementation of the settlement of criminal cases committed by children through an out-of-court process. ${ }^{14}$

In dealing with children in conflict with the law, the condition of children who are different from adults must always be considered. The nature of children as individuals who are still unstable, the future of children as national assets, and the position of children in society who still need protection can be used as the basis for finding an alternative solution how to prevent children from a formal criminal justice system, placing children in

12 Lilik Purwastuti Yudaningsih, 'Penanganan Perkara Anak Melalui Restorative Justice', Jurnal Hukum, Volume 13 Number 1, 2014, p. 71.

13 Eva Achjani Zulfa, 'Pergeseran Paradigma Pemidanaan di Indonesia', Jurnal Hukum $\mathcal{E}$ Pembangunan, 2017.

${ }^{14}$ I Made Tambir, 'Pendekatan Restorative Justice Dalam Penyelesaian Tindak Pidana Di Tingkat Penyidikan', Jurnal Magister Hukum Udayana, Volume 8 Number 4, 2019, p. 555. 
prison, and stigmatization of the child's position as a prisoner. The main objectives of restorative justice are to repair victims' losses, recognize perpetrators for losses due to crimes committed, conciliation or reconciliation between victims, perpetrators and the community, reintegration of perpetrators and through peaceful resolution of conflicts (peacefully resolved) can be managed by community security. ${ }^{15}$

Involvement of victims, affected communities, and perpetrators, it is also necessary to emphasize the importance of the involvement of trained professionals and special expertise on juvenile behavior in the process of restorative justice (juvenile justice professionals). Its roles include: facilitating mediation, determining certain places that are valuable to the community if community service obligations are to be performed by perpetrators, developing empathy groups and victim panels, organizing panels; communities, institutions or committees discussing with perpetrators for the benefit of victims, communities and perpetrators, facilitating the process of apologizing by perpetrators to community victims, raising awareness of victims and others.

There is a need for the main strategy to develop a sense of restorative responsibility, which consists of focusing on recovering victims' losses, organizing a process to safeguard the interests of the community, organizing a process to promote a broader understanding of the effects criminal acts have on other people and society, proposing meaningful ways for children to take responsibility for their actions, promoting apologies or expression of remorse for the perpetrator, and involving the victim and the community in determining the action of accountability.

The restorative justice approach provides opportunities and possibilities for crime victims to obtain repatriation, a sense of security, allows perpetrators to understand the causes and consequences of their behavior and take responsibility in a meaningful way and enables people to understand the root causes of crime, to promote community welfare and prevent crime. Restorative justice features a flexible range of actions that can be adapted to the prevailing criminal justice system and are complementary to take into account legal, social, and cultural conditions. The utilization of restorative justice will not harm the right of the state to prosecute suspected criminals.

Therefore, restorative justice or justice or deliberative-based justice is a diversion process, i.e., all parties involved in a crime must jointly solve problems and create an obligation to make things better by involving victims,

\footnotetext{
${ }_{15}$ Yul Ernis, 'Diversi Dan Keadilan Restoratif Dalam Penyelesaian Perkara Tindak Pidana Anak Di Indonesia', Jurnal Hukum, Volume 10 Number 2, 2015, p. 144.
} 
children, and community in seeking a solution to repair, reconciliation, and reassurance that is not based on retaliation. Justice based on deliberation and diversion in The Juvenile Criminal Justice System Law is important in its existence and is the main substance.

As stated in the Elucidation of the Juvenile Criminal Justice System Law, the most essential substance in this Law is a strict regulation on Restorative Justice and Diversion which is intended to avoid and keep children away from the judicial process to avoid stigmatization of children who are in conflict with the law, and it is hoped that children can return to the social environment properly. Therefore, it is essential for the participation of all parties in order to realize this. The process must aim at the creation of Restorative Justice, both for children and for victims. According to John Braithwaite, the concept of "restorative justice" refers to the informal conflict resolution process (not through a formal judicial process) carried out by the Maori community in New Zealand. It is a customary Maori practice recognized as legal by the government of New Zealand. It cannot be understood using Western legal theory. The realization of restorative justice in Indonesia during the Covid-19 pandemic is essential, considering the high level of spread of Covid-19 in Indonesia, including in prisons, and the situation in overcrowded prisons, including special prisons for children.

\section{B. Settlement of Child Crime in an Effort to Use Diversion as a Solution amid the Spread of Covid-19}

In the spread of Covid-19 in Indonesia, the Minister of Law and Human Rights, has made policies related to the settlement of child crimes based on diversion efforts outlined in the Decree of the Minister of Law and Human Rights Number M.HH-19.PK.01.04.04 of 2020 Regarding Release and Acquittal of Prisoners and Children Through Assimilation and Integration in the Context of Prevention and Control of the Spread of Covid-19. This Decree of the Minister of Law and Human Rights shows that the quality of protection for children has a degree or level that is at least the same as protection for adults, because everyone has the same position before the law (equality before the law). According to Arif Gosita, child protection is an effort that supports the implementation of the rights and obligations of the child itself. Therefore, a child who obtains and maintains the right to grow and develop in life in a balanced and positive manner means that he/she gets fair treatment and is protected from harmful threats. Efforts to protect children can be a legal 
action that has legal consequences, thus preventing children from arbitrary parental actions. ${ }^{16}$

The judicial process against children often loses its essential meaning as a mechanism that must end with efforts to protect the child's best interest. Juvenile criminal justice is often a process that is only oriented to formal law enforcement and is not oriented to the child's interests. ${ }^{17}$

In Restorative Justice Theory, the process of resolving legal violations that occur is carried out by bringing the victim and the perpetrator (suspect) together to sit in one meeting to talk together. In the meeting, the mediator provides an opportunity for the perpetrators to provide a clear picture of the actions they have taken. ${ }^{18}$ Restorative justice is a process in which all parties involved in a particular crime work together to solve the problem of how to deal with future consequences. ${ }^{19}$ In the development of criminal law, there has been a paradigm shift in the philosophy of juvenile criminal justice, which initially was retributive justice, then turned into rehabilitation, then finally became restorative justice. ${ }^{20}$ The transfer of the settlement of children's cases outside the formal channels of justice through diversion which is regulated in international children's instruments has juridical implications for Indonesia to accommodate the diversion provisions in the child legislation in Indonesia. ${ }^{21}$

In realizing the concept of Diversion as an instrument in Restorative Justice in the Juvenile Criminal Justice System based on Law Number 11 of 2012, which are the settlement of criminal cases involving the perpetrators, victims, families of perpetrators/families of victims, and other related parties to jointly seek a fair solution by emphasizing restoration to its original state and not retaliation.

Handling cases of children in conflict with the law that prioritizes children's best interests is still far from what is expected. The government has

${ }^{16}$ Hardianto Djanggih Syamsu Haling, Paisal Halim, Syamsiah Badruddin, 'Perlindungan Hak Asasi Anak Jalanan Dalam Bidang Pendidikan Menurut Hukum Nasional Dan Konvensi Internasional', Jurnal Hukum \& Pembangunan, Volume 48 Number 2, 2018, p. 362-363.

17 Achmad Ratomi, 'Konsep Prosedur Pelaksanaan Diversi Pada Tahap Penyidikan Dalam Penyelesaian Tindak Pidana Yang Dilakukan Oleh Anak', Jurnal Arena Hukum, Volume 6 Number 3, 2013, p. 395.

18 Arfan Kaimuddin, 'Perlindungan Hukum Korban Tindak Pidana Pencurian Ringan Pada Proses Diversi Tingkat Penyidikan', Jurnal Arena Hukum, Volume 8 Number 2, 2016, p. 260.

${ }_{19}$ Novi Edyanto, 'Restorative Justice Untuk Menyelesaikan Kasus Anak Yang Berhadapan Dengan Hukum', Jurnal Ilmu Kepolisian, Volume 11 Number 3, 2017, p. 41.

20 Yulia Kurniaty Purnama, Pancar ChandraJohny Krisnan, 'Pelaksanaan Diversi Ditingkat Pengadilan Berdasarkan Undang-Undang Nomor 11 Tahun 2012 Tentang Sistem Peradilan Pidana Anak', Varia Justicia, Volume 12 Number 1, 2016, p. 229.

${ }^{21}$ Nurini Aprilianda, 'Implikasi Yuridis Dari Kententuan Diversi Dalam Instrumen Internasional Anak Dalam Hukum Anak Di Indonesia', Jurnal Arena Hukum, Volume 5 Number 1, 2012, p. 40. 
issued special regulations governing the protection of children's rights in conflict with the law, such as Law Number 3 of 1997 Regarding the Juvenile Court, which was later revised to Law Number 11 of 2012 Regarding the Juvenile Criminal Justice System, and Law Number 23 of 2002 Regarding Child Protection. Even the government has ratified the Convention on the Rights of the Child (CRC) by issuing Presidential Decree Number 36 dated August 25, 1990, and signed the Beijing Rules agreement. However, it turns out that the provisions in the regulation are not the best solution for resolving cases of children in conflict with the law.

The special criminal justice system for children certainly has a particular purpose for the future interests of children and the community, which contains the principles of restorative justice. Article 1 section (6) of Law Number 11 of 2012 Regarding the Juvenile Criminal Justice System states that restorative justice is the settlement of criminal cases involving the perpetrator, victim, family of the perpetrator/victim, and other related parties to jointly seek a solution that is justice by emphasizing restoration to its original state, and not retaliation.

In the Juvenile Criminal Justice System, as mentioned in section (2), letters a and $b$, diversion must be sought. Diversion transfers the settlement of children's cases from the criminal justice process to processes outside of criminal justice. The diversion approach in restorative justice as regulated in Law Number 11 of 2012 Regarding the Juvenile Criminal Justice System is an unpopular breakthrough in the conventional criminal justice system. The issuance of the Juvenile Criminal Justice System Act confirms the protection of children in Indonesia. This law introduces the concept of diversion, which aims to provide protection for children in conflict with the law, children who are victims of criminal acts, and society in general as a form of diverting the settlement of children's cases from the judicial process to processes outside of criminal justice in order to realize justice. Restorative justice In the Government Regulation Number 65 of 2015 Regarding Guidelines for the Implementation of Diversion and Handling of Children Under the Age of 12 (Twelve) Years was issued, which is necessary for implementing Law Number 11 of 2012 Regarding the Juvenile Criminal Justice System.

Following up on the Juvenile Criminal Justice System Law and Government Regulation Number 65 of 2015 Regarding Guidelines for the Implementation of Diversion and Handling of Children Under the Age of 12 (Twelve) Years, within the scope of the Attorney General's Office, the Attorney General's Regulation of the Republic of Indonesia Number Per006/A/J.A/04/2015 Regarding Guidelines for the Implementation of Diversion at the Prosecution Level was issued. Meanwhile, the Supreme Court issued Regulation of the Supreme Court of the Republic of Indonesia Number 4 of 
2014 concerning Guidelines for the Implementation of Diversion in the Juvenile Criminal Justice System.

The Juvenile Criminal Justice System Law comes into force two years after the date of its promulgation that is 30 July 2012, as stated in its Closing Provisions (Article 108 of the Juvenile Criminal Justice System Law). This means that the Juvenile Criminal Justice System Law came into force on 31 July 2014. The current criminal acts in society are not only adults. There is even a tendency for the perpetrators to be classified as children. Therefore, various efforts to prevent and overcome child delinquency continue to be carried out. One of the government's efforts in preventing and overcoming delinquency is to organize a juvenile justice system through Law Number 11 of 2012 Regarding the Juvenile Criminal Justice System (after this referred to as the Juvenile Justice System Law) with the aim that it can make the realization of a judiciary that indeed guarantees the protection of the best interests of children in conflict with the law as the nation's successor.

One form of protection for children in conflict with the law is through diversion. The diversion model is intended to avoid and keep children away from the formal justice process to avoid stigmatization of children in conflict with the law, and it is hoped that children can return to the social environment naturally. Therefore, the participation of all parties is needed in order to make this happen. The process must aim at creating restorative justice, both for the child and for the victim. Diversion in restorative justice is a process where all parties involved in a particular crime work together to overcome problems and create an obligation to make things better by involving victims, children, and the community in finding solutions to repair, reconciliation, and reassurance that is not based on retaliation.

The implementation of diversion is motivated by the desire to avoid negative effects, especially on the soul and development of children that have the potential to occur if the completion of the criminal process is carried out through the criminal justice system. ${ }^{22}$ The application of diversion provisions is essential because, with diversion, children's human rights can be more guaranteed, and prevent children in conflict with the law from being stigmatized as naughty children because criminal acts suspected of involving a child as a perpetrator can be handled without the need to go through legal proceedings.

Using diversion in restorative justice, juvenile justice departs from the assumption that the response or reaction to child delinquency is not effective

\footnotetext{
${ }^{22}$ Rr. Putri A. Priamsari, 'Mencari Hukum Yang Berkeadilan Bagi Anak Melalui Diversi', Jurnal Law Reform, Volume 14 Number 2, 2018, p. 228.
} 
without the cooperation and involvement of victims, perpetrators, and the community. The underlying principle is that justice is best served when all parties receive fair and balanced attention, are actively involved in the judicial process and benefit adequately from their interactions with the juvenile justice system.

Diversion is carried out to impose more educational sanctions, not retaliatory, to create special prevention, which the goal to be achieved is to deter, improve, and make the criminals themselves unable to carry out these acts. The implementation of diversion is motivated by the desire to avoid adverse effects on the soul and development of children in their involvement in the criminal justice system, where the criminal justice system is more on justice that emphasizes retribution (retributive justice) and justice that emphasizes compensation (restitutive justice).

A child is at a very high risk of having their human rights violated when they have to be involved in the criminal justice system. So, it would be better if the diversion was applied in handling children's problems in conflict with the law. The fact is that criminal justice against children, perpetrators of criminal acts through the criminal justice system, poses more harm than benefits to children. This is because the court will stigmatize children for their actions, so it is better to prevent them from leaving the criminal justice system. ${ }^{23}$

The purposes of the implementation of diversion for children include: to prevent children from being detained, to avoid labeling children as criminals, to prevent the repetition of criminal acts committed by children, so that children are responsible for their actions, and to carry out the necessary interventions for victims and children without having to go through a formal process, to keep children away from the adverse effects and implications of the judicial process, to encourage children to take responsibility for their actions, to provide opportunities for children to make up for their mistakes by doing good for the victim, to provide opportunities for the victim to participate in the process, to provide opportunities for children to be able to maintain relationships with families and to provide opportunities for reconciliation and healing in the communities that criminal acts have harmed.

In essence, diversion also aims to prevent children from the negative effects of the application of crime. Diversion also has the essence of ensuring that children grow and develop. Thus, it can also be said that basically diversion has relevance to the purpose of punishment for children. In general,

\footnotetext{
${ }^{23}$ Marlina, Pengantar Konsep Diversi Dan Restorative Justice Dalam Hukum Pidana, Universitas Sumatera Utara, Medan, 2010, p. 261.
} 
the purpose of punishment consists of efforts to protect the community on the one hand and protect (the perpetrator) on the other. ${ }^{24}$

The criminal settlement through diversion aims to make the perpetrator aware that the crime committed cannot be justified and has harmed other parties. Therefore, if the diversion is successfully agreed upon by the parties concerned, especially the victim at the investigation level (Departmental Police), the child (perpetrator) will immediately get his rights restored. The implementation of diversion in the Police is a maximum of 30 (thirty) days (Article 29 Section (2) of the Juvenile Criminal Justice System Law), as well as in the Prosecutor's Office for a maximum of 30 (thirty) days (Article 42 Section (2) of the Juvenile Criminal Justice System Law), from then on in Court for a maximum of 30 (thirty) days (Article 52 Section (3) of the Juvenile Criminal Justice System Law).

The implementation of diversion is motivated by the desire to avoid the negative effects on the soul and development of children by being involved with the criminal justice system. The implementation of this diversion prioritizes efforts to protect children from imprisonment. Efforts to solve problems against children in conflict with the law do not always have to use formal legal channels, considering that a child may be said to be a person who cannot act legally. This is because a person is considered immature, and his actions cannot be legally accounted for. Therefore, the solution can be reached with various alternatives, one of which is by using a restorative justice model concept approach.

The advantages of implementing diversion for children are: children do not need to be detained (avoid detention), avoiding stigma or stamped as criminals, opportunities for children to improve life skills, opportunities for children to be responsible for their actions, do not repeat criminal acts, promoting necessary interventions for victims and perpetrators without having to through a formal process, preventing children from participating in the judicial system process by keeping children away from the negative influences and implications of the judicial process.

Based on the description above, it can be stated that the government's policy, represented by the Minister of Law and Human Rights, as stated in the Decree of the Minister of Law and Human Rights Number M.HH19.PK.01.04.04 of 2020 Regarding the Release and Acquittal of Prisoners and Children Through Assimilation and Integration in the Context The Prevention and Control of the Spread of Covid-19 is in line with the concept of diversion

${ }^{24}$ Purnama, Pancar ChandraJohny Krisnan. Op Cit. p. 225. 
adopted in criminal law in Indonesia. This has also been based on restorative justice and is very beneficial for the children's survival and the future of children who are prisoners amid the covid-19 pandemic.

\section{CONCLUSION}

Based on the description of the study, it was concluded that the handling of juvenile criminal cases through the concept of diversion based on restorative justice was carried out to guarantee and respect the dignity of the child, carried out in the best interests of the child and by considering justice for the victim. Settlement of Child Crimes through the Concept of Diversion as a Solution in the Middle of the Spread of covid-19. The government, which in this case is represented by the Minister of Law and Human Rights, has made a very responsive policy through the Decree of the Minister of Law and Human Rights Number M.HH-19.PK.01.04.04 of 2020 Regarding the Release and Acquittal of Prisoners and Children Through Assimilation and Integration in the Context of Prevention and Control of the Spread of Covid19 , this policy is in line with the concept of diversion adopted in criminal law in Indonesia. This has also been based on restorative justice and is very beneficial for the survival of children and the future of children who are prisoners in the midst of the covid-19 pandemic.

\section{DECLARATION OF CONFLICTING INTERESTS None}

\section{FUNDING INFORMATION}

None

\section{ACKNOWLEDGEMENT}

The author would like to thank the Master of Law at Diponegoro University, a good and comfortable place for writers to study law. The author also expresses his gratitude to Irma Cahyaningtyas as the second author and the author's supervisor in completing the writing of this article. Hopefully, this research will be useful for the development of legal science, especially regarding the protection of the rights of children facing the law during the covid-19 pandemic.

\section{REFERENCES}

Andora, H. (2016). Aktualisasi Nilai-Nilai Pancasila Dalam Pengadaan Tanah Bagi Pembangunan Untuk Kepentingan Umum. Masalah-Masalah Hukum, 45(2), 107-114. 
Aprilianda, N. (2012). Implikasi Yuridis Dari Kententuan Diversi Dalam Instrumen Internasional Anak Dalam Hukum Anak Di Indonesia. Jurnal Arena Hukum, 5(1), 31-41.

Arfan, K. (2016). Perlindungan Hukum Korban Tindak Pidana Pencurian Ringan Pada Proses Diversi Tingkat Penyidikan. Jurnal Arena Hukum, 8(2), 258-279.

Benuf, Kornelius, \& Muhamad Azhar. (2020). Metodologi Penelitian Hukum Sebagai Instrumen Mengurai Permasalahan Hukum Kontemporer. Gema Keadilan, 7(1), 20-33.

Ernis, Y. (2015). Diversi Dan Keadilan Restoratif Dalam Penyelesaian Perkara Tindak Pidana Anak Di Indonesia. Jurnal Hukum, 10(2), 136-47.

Haris, A. (2018). Equality before the Law Dalam Sistem Peradilan Di Indonesia. Lokataru Foundation, September 6, 2018, accessed from https://lokataru.id/equality-before-the-law-dalam-sistem-peradilan-diindonesia/.

Hidayati, N. (2013). Peradilan Pidana Anak Dengan Pendekatan Keadilan Restoratif Dan Kepentingan Terbaik Bagi Anak. Ragam, 13(4), 144-151.

Kania, D. (2014). Pidana Penjara Dalam Pembaharuan Hukum Pidana Indonesia. Yustisia, 3(1), 19-28.

Marlina. (2010). Pengantar Konsep Diversi Dan Restorative Justice Dalam Hukum Pidana. Medan: Universitas Sumatera Utara.

Mukti, F. \& Yulianto, A. (2017). Dualisme Penelitian Hukum Normatif Dan Empiris. Yogyakarta: Pustaka Pelajar.

Novi Edyanto, 'Restorative Justice Untuk Menyelesaikan Kasus Anak Yang Berhadapan Dengan Hukum', Jurnal Ilmu Kepolisian, 11.3 (2017), 31-52

Priamsari, R. P. A. (2018). Mencari Hukum Yang Berkeadilan Bagi Anak Melalui Diversi. Jurnal Law Reform, 14(2), 220-235.

Purnama, Pancar, C. J. K., \& Yulia, K. (2016). Pelaksanaan Diversi Ditingkat Pengadilan Berdasarkan Undang-Undang Nomor 11 Tahun 2012 Tentang Sistem Peradilan Pidana Anak. Varia Justicia, 12(1), 222-234.

Rahayu, S. (2015). Diversi Sebagai Alternatif Penyelesaian Perkara Tindak Pidana Yang Dilakukan Anak Dalam Perspektif Sistem Peradilan Pidana Anak. Jurnal Ilmu Hukum, 6(1), 127-142.

Ratomi, A. (2013). Konsep Prosedur Pelaksanaan Diversi Pada Tahap Penyidikan Dalam Penyelesaian Tindak Pidana Yang Dilakukan Oleh Anak. Jurnal Arena Hukum, 6(3), 394-407.

Satria, H. (2018). Restorative Justice: Paradigma Baru Peradilan Pidana. Jurnal Media Hukum. https://doi.org/10.18196/jmh.2018.0107.111-123. 
Shinta, A. (2015). Implementasi Asas Lex Specialis Derogat Legi Generali Dalam Sistem Peradilan Pidana. Masalah-Masalah Hukum, 44(4), 503-510. Sujatmiko, A. (2010). Perjanjian Lisensi Merek Terkenal. Mimbar Hukum, 22(2), 252-64.

Syamsu, H., et al. (2018). Perlindungan Hak Asasi Anak Jalanan Dalam Bidang Pendidikan Menurut Hukum Nasional Dan Konvensi Internasional. Jurnal Hukum \& Pembangunan, 48(2), 352-363.

Tambir, I. M. (2019). Pendekatan Restorative Justice Dalam Penyelesaian Tindak Pidana Di Tingkat Penyidikan', Jurnal Magister Hukum Udayana, 8.4 (2019), 530-558

Widayati, L. S. (2015). Ultimum Remedium Dalam Bidang Lingkungan Hidup', Ius Quia Iustum Law Journal, 22(1), 1-24.

Yudaningsih, P. L. (2014). Penanganan Perkara Anak Melalui Restorative Justice. Jurnal Hukum, 13(1), 67-79.

Zulfa, E. A. (2017). Pergeseran Paradigma Pemidanaan Dl Indonesia. Jurnal Hukum \& Pembangunan. https://doi.org/10.21143/jhp.vol36.no3.1256. 


\section{ABOUT AUTHOR(S)}

Karsudin is a student of the Master of Law program, Diponegoro University. Currently works as a lawyer, in Semarang.

Irma Cahyaningtyas is a lecturer who teaches at the Faculty of Law, Diponegoro University, in Semarang. 


\section{LEGAL ADAGE}

\section{EQUUM ET BONUM EST LEX LEGUM}

\section{What Is Just and Right Is the Law of Laws}

